\title{
Does preservation of active range of motion after acute elbow injury rule out the need for radiography?
}

\author{
Akut dirsek travmasından sonra aktif eklem hareket açıklığının korunması \\ radyografi gerekliliğini ortadan kaldırır mı?
}

\author{
Hassan AMIRI, ${ }^{1}$ Samad SHAMS VAHDATI, ${ }^{2}$ Sanaz FEKRI, ${ }^{2}$ Shayan Abdollah ZADEGAN, ${ }^{3}$ \\ Hamid SHOKOOHI, ${ }^{4}$ Vafa RAHIMI-MOVAGHAR ${ }^{3}$
}

\section{BACKGROUND}

We aimed to evaluate the role of a normal elbow active range of motion (ROM) in predicting low fracture risk and avoiding elbow X-ray in patients with acute elbow injuries. Lack of any approved rules for this purpose led us to evaluate simple physical examination methods to predict elbow fractures.

\section{METHODS}

In this observational study, all patients with elbow injury who presented to two emergency departments were enrolled according to specific criteria. Patients were examined by emergency or orthopedics residents. Elbow radiographs were reviewed by a radiologist for fractures and soft tissue injuries. Results of the clinical examination and radiographs were recorded for statistical analysis. Sensitivity, specificity and positive and negative predictive values were calculated.

\section{RESULTS}

Elbow fractures were identified in 10 of the 102 enrolled patients $(9.8 \%)$. Nine of the 10 had limited ROM in all movements. Limited active elbow ROM in predicting elbow fracture revealed a sensitivity of $90 \%$, specificity of $92 \%$, and positive and negative predictive values of $56 \%$ and $98 \%$, respectively. Individuals with limitation in one or two directions had no signs of fracture in the X-rays.

\section{CONCLUSION}

Patients with elbow injury and a limited ROM in all directions of flexion, extension, supination and pronation require further X-ray investigations.

Key Words: Elbow injury; range of motion; fracture; radiography.

\section{AMAÇ}

Akut dirsek travması geçiren hastalarda düşük kırık riskini öngörme ve dirseğin radyografik görüntülemesinden vazgeçmede normal aktif eklem hareket açıklığ1 (ROM) rolünü değerlendirmektir. Bu amaçla kabul edilen kuralların olmaması bizi dirsek kırıklarını öngörmede basit fiziksel inceleme yöntemlerini değerlendirmeye sevk etti.

\section{GEREÇ VE YÖNTEM}

$\mathrm{Bu}$ gözlemsel çalışmada dirsek travmasıyla iki acil servise gelen hastaların tümü spesifik ölçütlere göre çalışmaya alındı. Hastalar acil servis veya ortopedi asistanları tarafindan incelendi. Dirsek radyografileri bir radyolog tarafindan kırıklar ve yumuşak doku yaralanmaları açısından gözden geçirildi. İstatistiksel analiz için klinik inceleme ve radyografi sonuçları kaydedildi. Özgüllük, duyarlılık, pozitif ve negatif öngördürcü değerler hesaplandı.

\section{BULGULAR}

Çalışmaya alınan 102 hastanın 10'unda $(\% 9,8)$ dirsek k1rıkları tanımlandı. On hastanın 9'unda her dirsek hareketi (ROM) kısıtlanmıştı. Dirsek kırığını öngörmede kısıtlanmış aktif dirsek ROM'un duyarlılık, özgüllük, pozitif ve negatif öngördürücü değerleri sırasılyla \%90, \%92, \%56 ve \% 98 şeklindeydi. Bir veya iki yöne hareketlerde kısıtlaması olan kişilerin radyografilerinde hiçbir kırık belirtisi yoktu.

\section{SONUÇ}

Dirsek travması geçirmiş, her yöne fleksiyon, ekstansiyon, supinasyon ve pronasyon hareketlerinde ROM'u kisitlanmış hastalara ayrıca radyografisini çekmek gerekmektedir.

Anahtar Sözcükler: Dirsek travması; hareket erimi; kırık; radyografi.
${ }^{1}$ Department of Emergency Medicine, Tehran University of Medical Sciences, Tehran; ${ }^{2}$ Department of Emergency Medicine, Tabriz University of Medical Sciences, Tabriz; ${ }^{3}$ Sina Trauma and Surgery Research Center,

Tehran University of Medical Sciences, Tehran, Iran; ${ }^{4}$ Department of Emergency Medicine, George Washington University, Washington,USA.
${ }^{1}$ Tahran Üniversitesi Tıp Bilimleri, Acil Tıp Bölümü, Tahran; ${ }^{2}$ Tebriz Üniversitesi, Tıp Bilimleri, Acil Tıp Bölümü, Tebriz; ${ }^{3}$ Tahran Üniversitesi Tip Bilimleri, Sina Travma ve Cerrahi Araştırma Merkezi, Tahran, İran; ${ }^{4}$ George Washington Üniversitesi, Acil Tıp Bölümü, Washington, ABD. 
Elbow injury is one of the common complaints in the Emergency Department (ED), ranging from a complex fracture with neurovascular damage or simply a subtle or occult fracture. Despite a high rate of radiographs in elbow injury, it is one of the most important locations for missed fractures, reported as $10.8 \%$ and $6 \%$ in two different studies. ${ }^{[1-3]}$

Clinical decision rules for obtaining radiography in different injuries such as the Ottawa ankle and knee rules, cervical spine rules and Pittsburgh knee rules have led to efficient use of radiography in injuries..$^{[4-10]}$ These rules have led to a reduced number of radiographs and eliminated unnecessary exposure to radiation in patients. ${ }^{[10]}$

There are no validated clinical rules to predict the need for radiography in elbow injuries. Previous studies offered clinical rules by evaluating limitations in elbow active range of motion (ROM) to predict the need for an elbow X-ray. ${ }^{[1,11-13]}$ In several studies, the patient's ability to fully extend the elbow was suggested as a sensitive clinical screening test for patients with elbow injuries or in situations in which radiology facilities were lacking. ${ }^{[1,11-14]}$

In this study, we evaluated the role of a normal elbow active ROM following acute trauma as the predictor of low risk fracture with no need for further radiography. We hypothesized that maintaining full ROM of elbow in all movements (flexion, extension, supination, pronation) after trauma demonstrated low fracture risk in patients and that X-ray radiographs for every patient may not be required.

\section{MATERIALS AND METHODS}

This prospective observational study took place from April to September 2010. Enrollment sites were the EDs of two academic hospitals, with a census of approximately 57,000 annual emergency visits. All patients presenting to the ED with elbow injury were included. The inclusion criteria were as follows: age $>5$ years old, admission to the hospital in the first 24 hours, no evidences of an altered mental status or intoxication, no previous history of elbow trauma, vascular dysfunction or any other medical condition limiting baseline mobility of the elbow, and no other distracting injuries. All eligible patients chosen by census sampling method were included. ${ }^{[10]}$

Active ROM was examined and recorded by an orthopedics or emergency medicine resident. Participating physicians were instructed on how to perform the ROM and complete the enrollment form. Examination included active flexion of $90^{\circ}$ with a full extension $\left(0^{\circ}\right)$ and a normal and complete pronation and supination.

Patients who did not receive radiographs were excluded. Only the patients that underwent radiographic evaluations (according to the physician's clinical judgment) entered the study. All of them underwent routine $\mathrm{X}$-ray in lateral and anteroposterior (AP) positions. Other views were prescribed in those patients who did not have fracture in AP and lateral views, but were clinically suspected of fracture.

For all patients, the presence of fracture or displaced fat pad sign was followed by radiographs. An attending radiologist who was blinded to the results of the physical examination reviewed all radiographs. All data including baseline demographics were recorded on a standard form.

Patients were divided into two groups of normal and abnormal active ROM. Similar ROM on both sides was considered normal, so some normal cases had equal limitations in both hands.

Fracture and soft tissue injury (displaced fat pad sign) in the two groups were determined by means of radiographs.

Descriptive statistical tests were performed using the Statistical Package for the Social Sciences for Windows, version 18 (SPSS Inc., Chicago, IL). Mean, standard deviation (SD), percentage frequency, chisquare, and difference of means were calculated by a statistician investigator. Sensitivity, specificity, predictive values, and likelihood ratios were calculated.

\section{RESULTS}

One hundred and two patients $(66.7 \%$ males $)$ with a mean age of 32.2 \pm 21.6 years (range, 5-87 years) were enrolled according to the specific criteria. The most common mechanism of trauma was a fall and the most involved bone was the humerus.

Limited active ROM was identified in 26 patients (Table 1). Six patients had similar limitation on both sides and were considered normal. Twenty patients had significant limitations in the injured elbow compared to the non-injured side.

The X-ray showed fractures in 10 patients. Ninetytwo patients $(90.2 \%)$ had no sign of fracture on the X-ray.

Table 1. Results of elbow range of motion examination and radiographic evaluation $(\mathrm{n}=102)$

\begin{tabular}{lcc}
\hline Limitation in ROM & No fracture & Fracture \\
\hline No limitation & 81 & 1 \\
All movements & 7 & 9 \\
Supination + pronation & 2 & 0 \\
Flexion + extension & 1 & 0 \\
Extension & 1 & 0 \\
\hline
\end{tabular}

ROM: Range of motion; $\mathrm{p}<0.001$. 
Table 2. Types of fractures in 10 patients with positive $\mathrm{X}$-ray sign for fracture

\begin{tabular}{lcc}
\hline Type of injury & Mechanism of trauma & $\mathrm{n}$ \\
\hline Condylar fracture & Car accident & 3 \\
Olecranon fracture & Falling & 2 \\
Articular surface fracture & Falling & 2 \\
Intercondylar fracture & Falling & 1 \\
Lateral epicondylar fracture & Falling & $1^{*}$ \\
Radial head fracture & Violence & 1 \\
\hline
\end{tabular}

* A 26-year-old male with normal physical examination who had a fracture on X-ray.

Of 20 patients with limited ROM in the injured elbow, 9 (45\%) had elbow fractures on the X-ray. Humerus condyle fracture was the leading type of fracture, followed by olecranon fractures (Table 2). Of 82 patients who were considered normal, only 1 had radiographic fracture (Table 1).

All 9 patients with radiographic fractures had limitations in all movements $(\mathrm{p}=0.001)$.

Soft tissue injuries were detected in 15 patients (14.7\%). Of 20 patients with limited ROM, 13 (65\%) had soft tissue injury $(p=0.001)$. All 9 patients with radiographic fracture had soft tissue injuries. Of 82 patients who were considered as having normal ROM, 2 $(2.4 \%)$ had soft tissue injury.

Limited active ROM in injured elbows had a sensitivity of $90 \%$, specificity of $92 \%$, positive predictive value of $56 \%$, and negative predictive value of $98 \%$.

Patients with limitation in one or two movements (for instance, limited extension/flexion and normal supination/pronation) had no sign of fracture on X-ray.

\section{DISCUSSION}

This prospective observational study showed that a normal active elbow ROM examination following acute trauma may suggest the lack of acute fracture, with no need for further elbow radiography. Only one patient who presented with a normal active ROM was found to have a fracture on the elbow X-ray. Two other patients with normal examinations had a soft tissue injury on the X-ray.

In the literature, linear fracture of the head of the radius $^{[1,10-12]}$ and fracture of the olecranon ${ }^{[10-12]}$ were two injuries observed in patients with normal ROM. However, the addition of point tenderness at the olecranon, epicondyles and radial head did not improve the sensitivity or specificity of the active ROM maneuvers in the detection of elbow fractures. ${ }^{[10-12]}$

In our study, patients with partial limitation in one or two movements had no sign of fractures on the Xray. However, almost all patients with fracture had limited range in all movements. Thus, presence of lim- itation in all movements is more suggestive for predicting elbow fracture. In other words, limited elbow ROM in all movements is a good indicator for possible significant injury to the elbow, which may require further X-ray investigations. This study does not show any association among the different kinds of limited ROM in one direction and elbow fracture, which can be explained by the small number of patients in these groups.

We found limited elbow active ROM as a sensitive test for detecting fractures $(90 \%)$. Several studies have shown the sensitivity of elbow ROM in detecting fracture $\left(92 \%\right.$ in the study of Lamprakis et al., ${ }^{[13]} 96.8 \%$ in the large study by Appelboam ${ }^{[12]}$ and $100 \%$ in the study of Darracq $\left.{ }^{[10]}\right)$.

This test also showed acceptable specificity in our study (92\%). Lennon and Darracq both reported high specificity in active ROM tests as well, with rates of $91 \%$ and $97 \%$, respectively. ${ }^{[1,10]}$ Studies which relied only on full extension had lower specificity $(69.4 \%$ and $48.5 \%$ in the studies of Docherty and Appelboam, respectively). ${ }^{[12,14]}$

The active ROM is an easy test to perform in the ED and has been proven to be sensitive. Thus, the elbow clinical examination could help clinicians to efficiently use radiography for injured patients.

The possible explanations for the patient with a false-negative result of the examination (a positive elbow fracture with normal ROM examination) might be explained by the following factors: 1 . Opioid addiction or opium consumption; 2. Diabetic neuropathy; 3 . Presence of more severe pain and injury in different locations or confusion following head injury; or 4. Cervical spinal cord injury with upper extremity numbness. In the latter scenario, the patient cannot have normal active ROM, but can have normal passive ROM.

We found that individuals with preservation of full active ROM after acute elbow trauma have a very low risk of associated fracture and may not require radiographic investigation. The limitations of this study included the relatively small sample size. Further multicenter studies should be performed with larger numbers of patients and of longer duration with defined mechanism of injury, types of fractures, risk factors, outcomes of fracture, and disability rates.

\section{Acknowledgements}

We would like to thank Dr. Soheil Saadat for his great help in the statistical analysis.

\section{REFERENCES}

1. Lennon RI, Riyat MS, Hilliam R, Anathkrishnan G, Alderson G. Can a normal range of elbow movement predict a normal elbow x ray? Emerg Med J 2007;24:86-8. 
2. Freed HA, Shields NN. Most frequently overlooked radiographically apparent fractures in a teaching hospital emergency department. Ann Emerg Med 1984;13:900-4.

3. Wei CJ, Tsai WC, Tiu CM, Wu HT, Chiou HJ, Chang CY. Systematic analysis of missed extremity fractures in emergency radiology. Acta Radiol 2006;47:710-7.

4. Stiell IG, Greenberg GH, McKnight RD, Nair RC, McDowell I, Reardon M, et al. Decision rules for the use of radiography in acute ankle injuries. Refinement and prospective validation. JAMA 1993;269:1127-32.

5. Stiell IG, Greenberg GH, Wells GA, McDowell I, Cwinn AA, Smith NA, et al. Prospective validation of a decision rule for the use of radiography in acute knee injuries. JAMA 1996;275:611-5.

6. Stiell IG, Greenberg GH, McKnight RD, Nair RC, McDowell I, Worthington JR. A study to develop clinical decision rules for the use of radiography in acute ankle injuries. Ann Emerg Med 1992;21:384-90.

7. Stiell IG, Wells GA, McDowell I, Greenberg GH, McKnight $\mathrm{RD}$, Cwinn AA, et al. Use of radiography in acute knee injuries: need for clinical decision rules. Acad Emerg Med 1995;2:966-73.

8. Stiell IG, Wells GA, Vandemheen KL, Clement CM, Le- siuk H, De Maio VJ, et al. The Canadian C-spine rule for radiography in alert and stable trauma patients. JAMA 2001;286:1841-8.

9. Seaberg DC, Jackson R. Clinical decision rule for knee radiographs. Am J Emerg Med 1994;12:541-3.

10. Darracq MA, Vinson DR, Panacek EA. Preservation of active range of motion after acute elbow trauma predicts absence of elbow fracture. Am J Emerg Med 2008;26:779-82.

11. Hawksworth CR, Freeland P. Inability to fully extend the injured elbow: an indicator of significant injury. Arch Emerg Med 1991;8:253-6.

12. Appelboam A, Reuben AD, Benger JR, Beech F, Dutson J, Haig $\mathrm{S}$, et al. Elbow extension test to rule out elbow fracture: multicentre, prospective validation and observational study of diagnostic accuracy in adults and children. BMJ 2008;337:2428.

13. Lamprakis A, Vlasis K, Siampou E, Grammatikopoulos I, Lionis C. Can elbow-extension test be used as an alternative to radiographs in primary care? Eur J Gen Pract 2007; 13:2214.

14. Docherty MA, Schwab RA, Ma OJ. Can elbow extension be used as a test of clinically significant injury? South Med J 2002;95:539-41. 